\title{
"Ultimately about dignity": Social movement frames used by collaborators in the Food Dignity action-research project
}

\section{FoodDignity}

Lacey Gaechter a

Johns Hopkins Bloomberg School of Public Health

Christine M. Porter b*

University of Wyoming

Submitted September 27, 2017 / Revised January 29 and February 12, 2018 / Accepted February 13, 2018 /

Published online July 18, 2018

Citation: G aechter, L., \& Porter, C. M. (2018). “Ultimately about dignity”: Social movement frames used by collaborators in the Food Dignity action-research project. Journal of Agriculture, Food Systems, and Community

Development, 8(Suppl. 1), 147-166. https:// doi.org/ 10.5304/ jafscd.2018.08A.004

Copyright $\odot 2018$ by the Authors. Published by the Lyson Center for Civic Agriculture and Food Systems. Open access under CC BY license.

\begin{abstract}
Social movement theory suggests that effectively framing the cause of a problem (diagnostic framing), its solutions (prognostic framing), and reasons to support its solutions (motivational framing) is likely to be essential for reaching movement goals. In this paper, we apply social movement framing theory to empirically identify prognostic, diagnostic, and motivational frames in the growing food justice movement in the U.S. We use the case of the Food Dignity project, a five-year, U.S. D epartment of Agriculture (USD A)-funded, action

a Lacey G aechter, master's student at the University of Wyoming.

G aechter is now a doctoral student in Environmental Health and Engineering, Johns Hopkins Bloomberg School of Public Health; 615 North Wolfe Street; Baltimore, MD 21205 USA; lacey.gaechter@gmail.com

$\mathrm{b} *$ Corresponding author: Christine M. Porter, Associate Professor and Wyoming Excellence Chair of Community and Public Health; Food D ignity Principal Investigator; Division of Kinesiology \& Health, College of Health Sciences, University of Wyoming; 1000 East University Avenue, D epartment 3196; Laramie, WY 82071 USA; christine.porter@uwyo.edu
\end{abstract}

and research collaboration between academics and leaders at five community-based food justice organizations. We coded multiple data sources, both public and internal to the project, to identify the strongest and most common diagnostic, prognostic, and motivational frames used by 25 individual collaborators in the Food Dignity project. Results suggest that the majority of diagnostic frames used by Food D ignity partners did not relate directly to food, but included instead insufficient resources, loss of place, degraded com-

\section{Funding Disclosure}

Food D ignity (http:/ / www.fooddignity.org) was funded by USD A National Institute of Food and Agriculture's Agriculture and Food Research Initiative Competitive G rant no. 2011-68004-30074.

\section{Contributors and Supporting Agencies}

Blue Mountain Associates; Feeding Laramie Valley; Whole Community Project; East New York Farms!; Dig D eep Farms; University of Wyoming; and the U.S. D epartment of Agriculture National Institute of Food and Agriculture.

\section{Acknowledgements}

We are grateful to the action research teams of Food Dignity. 
munity, and constrained choice and responseability (Minkler, 1999) as causes of problemsthough a broken food system also emerged as a causal frame. Similarly, solution framing included one overarching food-related strategy, which we labelled "great food." The other prognostic frames were reclaiming power, growing the local economy, strengthening community, fostering sustainable organizations, and networking. We did not find any motivational frames in the first round of semi-open coding. However, when we returned to reexamine the data with a hypothesis informed by our project experience beyond the textual data, we identified the motivational frame that we call recompense. Recompense suggests that those who have benefited from our current food systems should now work toward justice for those who sacrificed, usually unwillingly, to create them. This frame was mostly used indirectly and by community-based (rather than academic) partners in the project. Identifying these food justice diagnostic, prognostic, and motivational frames may help movement leaders to more explicitly examine and employ them and is an essential step for future research in assessing their effectiveness for creating a just, sustainable and healthy food system.

\section{Keywords}

Social Movement Framing; Social Movement Frames; Food Dignity; Sustainability; Food Justice; Diagnostic Framing; Prognostic Framing; Motivational Framing; Just Food System; Structural Oppression; Racism; Community Food Security; Food Sovereignty;

\section{Introduction}

Thousands of people and organizations align themselves with the community, national, and/ or international food justice movement. O ne scholar defines this movement as "a budding social movement premised on ideologies that critique the structural oppression responsible for many injustices throughout the agrifood system" (Sbicca, 2012, p. 455).

Social movement theory suggests that effectively framing the cause of a problem (diagnostic framing), its solutions (prognostic framing), and the reasons to support its solutions (motivational framing) is likely essential for reaching the movement's goals. Little empirical examination of the social movement framing employed within the food justice movement has been conducted. However, social movement theory suggests that the way in which movement actors frame the problems they are trying to solve affects how successful they are in doing so (Buechler, 2000; Martin, 2015; Snow \& Benford, 1988). Thus, identifying the social movement frames that food justice leaders use is a first step in assessing and improving the frames' effectiveness. This study identifies the diagnostic, prognostic, and motivational frames used by individual and organizational partners in a food justice actionresearch partnership called Food D ignity.

Food Dignity is a participatory education, extension, and research project, funded from 2011 to 2016 by a US $\$ 5$ million USD A National Institute of Food and Agriculture's Agriculture and Food Research Initiative grant (including a no-cost extension to early 2018). Its primary research objective was to "identify, develop, and evaluate scalable and equitable strategies for organising sustainable community food systems to ensure food security" (Porter, Herrera, Marshall, \& Woodsum, 2014; spelling is British from the original). Food Dignity's organizational partners include five community-based organizations (CBOs) that lead and support community food justice work, in addition to academic partners assisting CBO s with project research.

The five CBO s are Blue Mountain Associates (BMA) in Wind River Indian Reservation, Wyoming; Feeding Laramie Valley (FLV) in Laramie, Wyoming; Whole Community Project (WCP) in Ithaca, New York; East New York Farms! (ENYF) in Brooklyn, New York; and Dig D eep Farms (D D F) in the unincorporated areas of Ashland and Cherryland in the Bay area of California. The academic partners are primarily at University of Wyoming (UW) and Cornell University, along with Ithaca College and University of California, D avis. In addition, the leader of the umbrella organization for FLV, Action Resources International, played a project wide role as community-university liaison. An introduction to the work of each partner 
organization is available on the project website (http:/ / www.fooddignity.org). Most of the partners in the Food Dignity project, both community-based and academic-based, align themselves explicitly with the food justice movement (Bradley \& Herrera, 2016).

\section{Literature Review}

A social movement can be defined as "collective forms of protest or activism that aim to affect some kind of transformation in existing structures of power" (Martin, 2015, p. 1). Frames are linguistic tools that package messages in ways that shape their meanings (Bateson, 1972; G offman, 1974/ 1986). Much in the same way a window frame shapes one's view and a frame around a painting influences one's perception of the painting, social movement frames influence both what messages audiences receive and how they perceive them. For example, one "window frame" on viewing food security suggests that food needs to stay cheap so poor people can afford it. Another is that full-time work should pay living wages that enable people to pay the real costs of healthy food. The first frame puts food prices in view and wages out of view; the second includes both wages and food prices. Likewise, vocabulary and phrasing can influence the meaning of similar messages. For example, in "all people deserve access to food" vs. "access to food is a human right," the former invites the reader to view the message that everyone should have enough food through a moral frame, and the latter offers this message through a legal frame.

Social movement scholars have identified a trio of frame types that movement leaders and members use to further their causes (McCammon, Muse, Newman, \& Terrell, 2007; McVeigh, Myers, \& Sikkink, 2004; Snow \& Benford, 1988):

- Diagnostic frames implicate or explain causes of problems the movement is addressing.

- Prognostic frames imply or suggest solutions to those problems.

- Motivational frames aim to persuade people to join or contribute to a movement.

Well-constructed diagnostic, prognostic, and motivational frames are theorized to lead to partici- pant mobilization (Snow \& Benford, 1988) and movement success (Buechler, 2000; Martin, 2015).

The small body of empirical research studying the impacts of social movement framing offers some evidence for causal links between framing and movement success or failure. As outlined below, this literature examines the success of framing in advocacy for homelessness prevention (Cress \& Snow, 2000), recruitment into the $\mathrm{Ku}$ Klux Klan (McVeigh, Myers, \& Sikkink, 2004), and women's efforts to gain access to serve on juries (McCammon, Muse, Newman, \& Terrell, 2007).

Framing in Homelessness Prevention Cress and Snow (2000) evaluated the success of framing among social movement organizations devoted to confronting homelessness. To do so, they conducted retrospective case studies of 15 such organizations to determine the importance of six theorized contributors to social movement success (viable organizations, sympathetic city council allies, existence of a city agency to address homelessness, disruptive tactics, articulate and specific diagnostic frames, articulate and specific prognostic frames). Using qualitative comparative analysis, they found that the organization's viability and the presence of articulate, specific diagnostic and prognostic frames were the only three necessary conditions to achieving a significant impactdefined as accomplishing at least two out of three predetermined outcomes. Furthermore, they stated that "articulate and focused framing activity comes more closely than any of the other conditions to constituting a necessary condition for attainment of the outcomes in question" (Cress \& Snow, 2000, p. 1100). The authors hypothesize that frames may be necessary conditions for success because frames are used to secure other conditions for success, including city support, allies, and viability (Cress \& Snow, 2000).

Framing in Ku Klux Klan Recruitment $\mathrm{McV}$ eigh et al. (2004) similarly attempted to verify the efficacy of frames, but did so by testing hypothesized outcomes against actual outcomes in a study of Ku Klux Klan (KKK) membership in Indiana in the 1920s. The authors note that KKK frames are anti-immigrant, anti-Catholic, anti- 
African American, and anti-free trade. They hypothesized that, if these frames were effective, KKK membership would be most concentrated in Indiana counties where the highest percent of immigrants, Catholics, or African Americans lived - that is, counties in which animosity among white, native-born Protestants was hypothesized to be highest. They also thought that counties that were most dependent on agriculture would offer the highest percentages of KKK recruits, given that farmers had little to gain and much to lose from free trade. The authors found that KKK membership was, indeed, positively correlated with all the demographic characteristics targeted by typical KKK framing except for Protestantismperhaps due to unreliable census data on religion. These correlations offer evidence that antiimmigrant, racial, and free trade framing was effective in aiding the Klan's recruitment efforts (McVeigh et al., 2004).

Framing in Women's Access to Jury Service Finally, McCammon et al. (2007) provided an additional quantitative assessment of the importance of framing in movement success. These authors coded frames that were used to promote the right of women to sit on juries in 15 U.S. states between 1913 and 1966. Using logistic regressions, they tested hypothesized correlations between the use of these frames and the success of policy change, as moderated by dominant cultural contexts. All years in which women did not win the right to sit on their respective state's juries were considered failures, and the year that the law did pass in that state was considered a success. Their findings indicate that:

- Frames that tapped into general hegemonic discourse (language of what is considered "normal") were not positively correlated with outcomes. For example, emphasizing dominantly accepted differences between men and women did not lead to women gaining access to juries.

- Capitalizing on legal hegemonic discourse was positively correlated with successful changes in juror statutes (e.g., the use of jurying as a citizen's duty).
- Consistently rebutting opposition frames (i.e., having the last word) was positively correlated with the passage of women juror laws.

- Frames that made use of a disruption in hegemonic discourse (e.g., the outbreak of WWI and WWII provided new opportunities for framing women as supporting the war effort by filling "men's roles" like jurors) were correlated with success (McCammon et al., 2007).

As can be gleaned from the above discussion, the body of empirical evidence for the impact that framing has on social movement success is small, but existing results support its importance.

Framing in Food Justice and Related Movements An even smaller body of social movement literature examines food movement frames, although not for causal inferences. O ne scholar has examined overall framing of "food sovereignty" (defined here as a radical and structural transformation of the global food system toward serving the needs of all people) and "community food security" (defined here as working within existing structures to ensure adequate community access to food) on the websites of 46 U.S.-based organizations in comparison and contrast with international use (Fairbairn, 2012). She concluded that "the type of political action recommended by U.S. organizations is certainly tame compared to that undertaken by some of their international counterparts- I could not find a single call to commit civil disobedience" (Fairbairn, 2012, p. 224). She also identified a perhaps problematic conflation of food localization and food sovereignty. Food localization, Fairbairn (2012) notes, originally simply meant eating food grown within one's own, self-defined community. She found, though, that this term has accumulated meanings associated with, for example, fairly traded or organically raised food, regardless of its origin.

Based on years of participant observation, another scholar uses broad social movement theories for defining what constitutes a movement to assess if there is such a thing as a "local food movement." Her conclusion was positive, finding that the movement offers "a new cosmology (or 
paradigm) of food production, distribution, and consumption" that includes "remarkable (but not unprecedented) use of pleasure to move political analyses forward" (Starr, 2010).

In a study that examines more explicitly the role of social movement framing theory in the food justice movement, Sbicca (2012) examined who does the framing of food justice via a descriptive case study with the People's G rocery, a food justice CBO in West Oakland, Califormia. The author found that organizational leaders consistently used anti-oppression diagnostic and prognostic framings of food justice. Interns of the People's G rocery, however, were less connected to those frames, and community members generally did not take part in the framing process at all.

At a more macro level, without using systematic text analysis methods, another paper examined consensus, or lack thereof, in frames used in hunger and malnutrition, community food security, and intentionally disruptive agricultural protest work (Mooney \& Hunt, 2009). Mooney and Hunt noted that prognostic framing, at least, differs within and between these arenas, and they closed with a call for more research on their diagnostic, prognostic, and motivational framing.

With this paper, we begin to answer that call with a project using empirical data coding and analysis to identify and characterize the diagnostic, prognostic, and motivational frames used by the individuals and organizations partnering in the Food D ignity project. Explicitly articulating these frames, as we do in this paper, is one important step toward (1) aiding movement actors in intentionally honing, shifting, or amplifying their framing; (2) assessing framing effectiveness for reaching movement goals; (3) facilitating discussion, debate, and ultimately ownership of movement framing by those most impacted by unjust food systems; and (4) identifying areas that might be ripe for deepening collaboration and coordination with other social movements.

\section{Methods}

In this section we outline our methods for case and participant selection, data collection and selection, and analysis.

In the analysis, we identify the individual project partners working with the five $\mathrm{CBO}$ s (and the community-university liaison) as "community." We identify those working for one of the four university and college partner institutions, including graduate students and staff, as "academic." The "we" used here represents the two academic coauthors. G aechter was a masters student at the University of Wyoming (UW) from 2014 to 2016. Her studies were funded by Food Dignity and this work draws from her thesis research. Porter was Gaechter's thesis chair at UW and is the project director and principal investigator of the Food Dignity project.

\section{Case Selection}

The Food Dignity project offers a rich case for an in-depth qualitative analysis of social movement framing in the food justice movement. A diverse range of critics sees the project as a potential vanguard for community-academic collaboration in food, justice, and food justice. Both activists and academics have called the project "groundbreaking" (Aarons, 2012; Cabbil, 2012; Chappell, 2013). In 2014, the project won the Community-Campus Partnerships for Health Award for its "extraordinary" and "outstanding" work in this realm (Community-Campus Partnerships for Health, 2014). In addition, since it is also a research project, Food Dignity offers a large "buffet" of rich and descriptive data for analysis. With nine organizations and about three dozen people collaborating on food justice action research, it is an atypical case - one that is valuable for its unique rather than representative qualities (Flyvbjerg, 2006). At the same time, the five CBO partners in the project are arguably broadly and roughly representative of community-based, communityled organizational work for food justice in the U.S.: they are urban, suburban, and rural; they are led by and serve people of diverse backgrounds; and their goals range from meeting basic nutritional needs to dismantling oppressive systems. Thus we believe that Food Dignity supplies a useful case for empirically identifying framing strategies within the U.S. community food justice movement.

Perspectives and Participants

In this study, we examined frames used by the five 
community organizations partnering in Food Dignity and 25 individual community and academic members of the Food Dignity team. These 25 individual members either attended the final meeting of project partners in early 2016, produced a first-person video story in 2015, or did both (15 of them). With the exception of Gaechter, who attended the final meeting as a note-taker, no one who met one or both of these criteria was excluded from our analysis.

O ur 25 individual participants consisted of 17 community-based and nine academic-based partners, including one person whose frame use is considered here under both "bases" because his role included both community and academic work over the course the project. Of the community partners, 10 publicly identify as people of color (half female, half male), six do not (three female and three male), and one male partner's public racial identity is unknown. Of the nine academicbased partners, two identify as people of color (one female, one male). The remaining seven include two male and five female academics (including Porter) who do not identify as people of color. None of the participants publicly identified as a gender other than female or male. These participant numbers are too small to draw any conclusions by associating movement framing use with certain demographics. We still identify, however, each data source cited in the results section by organizational affiliation (community or academic), race (of color or not) and gender (female or male) because of the important role that demographics likely play in movement framing (Sbicca, 2012; Slocum, 2011).

\section{Data Collection and Selection}

To identify the social movement frames used in the Food D ignity project, we selected and analyzed six kinds of Food D ignity data sources: (1) Gaechter's participation and observation with field notes, (2) collaborative pathway models produced with each of the five CBO s, (3) 16 first-person digital stories and their transcripts, (4) a project video about making those stories and its transcript, (5) meeting notes, and (6) text on the bome and about pages of the Food Dignity and CBO partner websites. More details on each are provided below. We selected these six sources from a much larger body of data collected by, with, and from partners over the five years (plus two no-cost extension years) of project funding. Our goals in making selections of which sources to analyze, largely via coding, for this framing analysis included:

- To represent the most current and most developed framing in use, we chose sources that were collected or created in 2014 or later;

- To analyze framing in work intentionally created for public audiences, we selected several sources- the websites, collaborative pathway models, and videos- that are highly developed products;

- To capture individual collaborator voices in both internal and public communication, we included the videos, meeting notes, and participation and observation data; and

- To capture organizational framing used by the CBO s in a more collective manner, we chose to analyze the websites, project video, and the five collaborative pathway models.

In total, these sources represent 23 text files containing 25 individual voices and, in the case of the collaborative pathway models and websites, public voices of the five CBO s. Together, these sources compose the most developed and intentional framing of food work within the catalogue of Food Dignity data combined with the richest records of internal discussions among project partners (Porter, 2018). We find that this set of data represents the major framing themes used by individual and organizational partners in the latter years of the Food D ignity project, based on our participation and observation as well as review of this manuscript by other partners.

\section{Participation and observation}

Gaechter conducted formal participation and observation with Food Dignity partners in three instances: volunteering with CBO partner FLV in 2014, serving as note-taker at a Union of Concerned Scientists meeting on food equity with three other Food D ignity collaborators (including Porter) in June 2015, and taking notes at the final, four-day, 
all-team project meeting in January 2016. Both her field notes and meeting notes were consulted and coded during textual analysis.

Additional participation and observation that informs our analysis, but is not included in the text coding analysis described, includes $\mathrm{G}$ aechter serving as formal note-taker for all-day research planning meetings of the four-member leadership team responsible for steering work in the final, nocost-extension years of the project. She took notes for the meetings in May 2016 and again in January 2017. Porter has been participating in and observing Food D ignity since inventing the plan for the project with collaborators in mid-2010. In addition to being one of the 25 individual "subjects" of this study, her experience and history in the project informed and influenced data interpretation.

\section{Collaborative pathway models}

Collaborative pathway modeling is a participatory method for articulating theories of change underlying an organization's programs by linking each activity to expected outcomes. The final model, with some parallels to detailed and rigorous logic modeling, connects every activity or initiative to actual or desired short-, medium-, and long-term outcomes. Two Food Dignity team members worked closely with each CBO partner in Food Dignity to co-develop a model of its program activities and expected outcomes (Hargraves \& D enning, 2018, in this issue). In this study, we included in our analysis the text in each of the five Food Dignity collaborative pathway models, one representing each $\mathrm{CBO}$ 's work. Because the models explicitly link action to expected outcomes, they offer rich data on prognostic frames. We exported the text within the models from the modeling software ${ }^{1}$ and included it in the coding analysis described below.

\section{Digital story videos and documentary}

Over the course of a three-day workshop in February 2015, with help from professional video story coaches from StoryCenter, four academic partners and 12 community partners each created a narrated digital story (Food Dignity, 2015). Their

\footnotetext{
1 http:// www.evaluationnetway.com
}

"assignment" was to create a 2-to-3 minute, firstperson story about their journeys to community food work (A. Hill, personal communication, January 12, 2015). StoryCenter also collaborated with Food Dignity to compile a 15-minute minidocumentary on the process of creating these digital stories called Tracing the Paths: Telling Stories of Food Dignity (Luotto, 2015). We viewed and transcribed the 16 digital stories and the minidocumentary for analysis.

\section{Websites}

We used the home or about pages from the Food Dignity website and four of the five partner CBOs to find respective missions and visions. We then used the mission or vision to explicitly identify the problem each CBO aims to help resolve, as listed in the first results section. For the fifth $\mathrm{CBO}$, which did not have its own website, we used the text provided for its partner page on the Food Dignity website.

Notes from final Food Dignity team meeting In the final team meeting of Food Dignity project collaborators, held in early 2016, 26 people (including $\mathrm{G}$ aechter and Porter) spent four days discussing what they had accomplished and learned over our five years together and what we should share "with the world" as results. Both authors and other participants took turns making detailed notes during group discussions. Note-takers aimed to capture the nuance of what each speaker shared, including some "live" transcriptions of exact wording, indicated with quotation marks. The result was 43 typed, single-spaced pages of notes. These were included in the coding analysis described below.

Data Analysis

In consultation with Porter, Gaechter analyzed the data above following Miles and Huberman's (1994) four-stage process:

1. Noting themes: We qualitatively reviewed all data sources described above and noted our initial observations about themes and questions.

2. Reducing data according to research questions: 
Using software (ATLAS.ti G mbH, 2008), Gaechter coded the textual data noted above, organizing what Miles and Huberman (1994) called themes specifically into diagnostic, prognostic, and/ or motivational framing categories. She also inductively developed initial codes for subthemes in each of these three categories. In this way, "theme" became synonymous with frame type (diagnostic, prognostic, or motivational), and "subtheme" became synonymous with frame. Porter reviewed and agreed with first author's coding, adding only a small handful of additional passages coded as representing these frames and suggesting additional frames within identified themes.

3. Displaying data in relevant categories: $\mathrm{We}$ exported all the coded text quotes from the data set into diagnostic, prognostic, and/ or motivational framing categories, with quotations also identified by frame.

4. Identifying and analyzing themes within each category: $\mathrm{G}$ aechter re-examined the coded passages and refined her frames analysis within each of the three overarching social movement framing categories. We then developed the methods described below to assess their strength.

After naming the problem each CBO was addressing, by inverting its vision or mission statements into problem statements, we then identified and assessed the strength of diagnostic, prognostic, and motivational frames as detailed below.

\section{Identifying strength of diagnostic frames}

After coding, we chose to focus our analyses on the diagnostic frames that were "strongest" by virtue of being both frequent (total number of passages using a particular diagnostic frame) and common (appearing across multiple data sources). Post-hoc, having adjusted for the total quantity of passages coded as "diagnostic" frames, we developed the following criteria to determine which frames were the "strongest":
1. Frequent $=$ diagnostic frames that were represented by 10 or more coded quotations. (This cut-point was inductively set, in that the diagnostic frames emerged as represented in either 10 or more coded passages, or by six or fewer.)

\section{AND}

2. Common $=$ frame appears in five or more individual text files. (D evelopment of this cut-point was informed by this level of commonality being consistent with dominant frames we perceived and notedduring our much larger body of participation and observation data- as salient across many organizations and individuals collaborating in the Food Dignity project).

\section{Identifying strength of prognostic frames}

The collaborative pathway model developed with each CBO explicitly identifies its strategies for accomplishing its mission. Thus we deemed any prognostic frame that appears in the long-term outcomes of three or more of the five models as "strong" in our analysis, even if it was not otherwise especially frequent or common. We also quantified the overall frequency of each prognostic frame in the collaborative pathway models in activities and outcomes (short-, mid-, and longterm). We additionally counted a prognostic frame as "strong" if it appeared in 30 or more coded passages, even if it did not appear in the long-term outcomes of three or more collaborative pathway models. This cut-point is higher than the 10 for diagnostic frequency above because the collaborative pathway model data set yielded so many prognostic quotations. As with diagnostic frame frequency, this cut-point is also informed by a posthoc gap noted between frame frequency.

\section{Identifying motivational frames}

No motivational frames emerged during the data reduction or display stages (Miles \& Huberman, 1994) of our analysis. During participation and observation, however, Gaechter noted that Food Dignity partners do explain (and have explained to both authors) why we, and why our society at large, 
should act on the diagnostic and prognostic frames they present. Based on this observation, we reviewed our field notes, and Porter selectively reviewed additional data such as meeting notes and team emails to further develop the characterization of this motivational frame. Then, to build a description of the motivational frame that emerged from this process using the data set selected for analysis in this study, we re-coded digital story and video transcripts, collaborative pathway model texts, and meeting notes (Merriam, 2009).

The results section below describes the strongest frames within diagnostic and prognostic framing categories as well as the single, and more implicit, motivational frame employed by partners in the Food Dignity project.

\section{Who is framing}

In the examples provided to illustrate each frame, we identify who is employing that frame by organizational affiliation (community or academic), racial identity (of color or not), and gender identity (female or male) in our group of 25 individual Food D ignity partners. ${ }^{2} \mathrm{O}$ ur population is too small to analyze the data meaningfully through a demographics lens, but we nonetheless chose to provide it for descriptive purposes.

\section{Checking our analysis}

In member checks with three community partners (all females, one of whom publicly identifies as a person of color), one partner who served as both an academic and community partner (male person of color), and three additional academic partners (all female, none is a person of color), participants indicated that our findings shared below are consistent with their experience.

\section{Results}

Food D ignity partners clearly define the problems they are working to address and offer many expla-

\footnotetext{
2 The racial and gender identities derive from how the partners have self-identified over the course of the project. The use of "not a person of color" to categorize those who identify as white is our own moniker, selected intentionally as the inverse of the more commonly used category "non-white." (Our category name centers people of color as the norm; "nonwhite" centers Caucasians as the reference population.)
}

nations as to why we have these problems (diagnostic frames) and what we should do to address them (prognostic frames). Eleven specific diagnostic and prognostic frames emerged as "strong" according to our criteria above. O nly one specific motivational frame was found in the data sources we analyzed, and we identified it only via the deductive analysis explained above. We describe each specific frame in detail below, and Table 1 summarizes each frame and characterizes its strength in terms of frequency and commonality.

In addition to naming summary demographics of individual speakers, we identify the data source for each example used in the results (where "story(ies)" = first person digital story or stories, "documentary" = Tracing the Patbs: Telling Stories of Food Dignity, "model(s)" = collaborative pathway model(s), and "notes" = meeting notes taken during final Food Dignity meeting).

\section{Problems Food Dignity Partners Are Working to Address}

The primary problems Food Dignity partner $\mathrm{CBO}$ s are trying to address are listed below. These are inversions of each organization's mission or vision statement:

- Unmet health and human services needs (BMA, n.d.)

- Insufficient access to healthy food and jobs (DDF, n.d.)

- Food injustice (ENYF, 2010)

- Food insecurity and an inequitable, unjust, and unsustainable food system (FLV, n.d.)

- Ill health of our children and youth (WCP at Food Dignity, n.d.)

- Community knowledge for how to address unsustainable community food systems leading to food insecurity is unacknowledged or unrecognized by institutions and agencies (Food Dignity, n.d.).

Addressing these problems can be considered the goal of the social movement framing used by the CBOs and Food Dignity partners, as identified below. 
Table 1. The Strongest Diagnostic, Prognostic, and M otivational Social Movement Frames used by Food Dignity Academic and Community-based Partners

\begin{tabular}{|c|c|c|}
\hline $\begin{array}{l}\text { Diagnostic } \\
\text { Frames }\end{array}$ & $\begin{array}{l}\text { Meaning } \\
\text { - The problems identified in CBO mission or vision statements } \\
\text { exist because (of) ... }\end{array}$ & Strength \\
\hline $\begin{array}{l}\text { Insufficient } \\
\text { Resources }\end{array}$ & $\begin{array}{l}\text { - individuals' and organizations' lack access to resources. } \\
\text { - resources are intentionally withheld from community } \\
\text { organizations. } \\
\text { - a lack or withholding of resources prevents community leaders } \\
\text { from being fully effective. }\end{array}$ & $\begin{array}{l}\text { Frequency: } 29 \\
\text { Commonality: } 5 \text { (notes, } \\
\text { documentary, } 2 \text { stories, } 1 \text { model) }\end{array}$ \\
\hline $\begin{array}{l}\text { Broken Food } \\
\text { System }\end{array}$ & $\begin{array}{l}\text { - insufficient access to (healthy) food, including through barriers } \\
\text { to growing one's own food. }\end{array}$ & $\begin{array}{l}\text { Frequency: } 19 \\
\text { Commonality: } 8 \text { ( } 3 \text { stories, } \\
\text { documentary, notes, } 3 \text { models) }\end{array}$ \\
\hline Loss of Place & $\begin{array}{l}\text { - loss of place through geographic relocation. } \\
\text { - loss of place due to a change in social context such as a } \\
\text { change in employment or demographic changes to one's } \\
\text { neighborhood. }\end{array}$ & $\begin{array}{l}\text { Frequency: } 16 \\
\text { Commonality: } 8 \text { ( } 5 \text { stories, } 2 \\
\text { models, notes) }\end{array}$ \\
\hline $\begin{array}{l}\text { Degraded } \\
\text { Community }\end{array}$ & $\begin{array}{l}\text { - poverty with little to no local economy or employment } \\
\text { opportunities. } \\
\text { - } \text { neglect and/ or abandonment of neighborhoods. } \\
\text { - lack of options for youth. } \\
\text { - } \text { unsafe environments. }\end{array}$ & $\begin{array}{l}\text { Frequency: } 14 \\
\text { Commonality: } 7 \text { (4 stories, } 3 \\
\text { models) }\end{array}$ \\
\hline $\begin{array}{l}\text { Constrained } \\
\text { Choice and } \\
\text { Response-ability }\end{array}$ & $\begin{array}{l}\text { - historical and lifetime trauma limiting personal capacity to } \\
\text { struggle against oppressive circumstances. } \\
\text { - systems that (intentionally) limit individual options and/or } \\
\text { choice. }\end{array}$ & $\begin{array}{l}\text { Frequency: } 10 \\
\text { Commonality: } 6 \text { ( } 3 \text { stories, notes, } \\
\text { documentary, } 1 \text { model) }\end{array}$ \\
\hline $\begin{array}{l}\text { Prognostic } \\
\text { Frames }\end{array}$ & $\begin{array}{l}\text { Meaning } \\
-\quad \text { To address the problems we should... }\end{array}$ & Strength \\
\hline Reclaiming Power & $\begin{array}{l}\text { - } \text { help local communities retake control of their food system. } \\
\text { - } \text { recognize and develop community leadership, including youth. } \\
\text { - } \text { connect communities with decision-makers. } \\
\text { - } \text { reclaim community and indigenous knowledge. }\end{array}$ & $\begin{array}{l}\text { In all } 5 \text { models as long-term } \\
\text { outcomes. } \\
\text { Frequency: } 59 \\
\text { Commonality: } 9 \text { (all } 5 \text { models, } \\
\text { appearing in a total of } 49 \text { short-, } \\
\text { mid-, and long-term outcomes; } 2 \\
\text { stories, notes, documentary) }\end{array}$ \\
\hline Local Economy & - improve the local (food) economy and create jobs. & $\begin{array}{l}\text { In } 4 \text { out of the } 5 \text { models as long- } \\
\text { term outcomes. } \\
\text { Frequency: } 30 \\
\text { Commonality: } 5 \text { ( } 4 \text { models in } 29 \\
\text { outcomes, } 1 \text { story) }\end{array}$ \\
\hline Strong Community & $\begin{array}{l}\text { - create a strong, socially connected, and safe community in } \\
\text { which people are proud to live. }\end{array}$ & $\begin{array}{l}\text { In } 4 \text { models as long-term } \\
\text { outcomes. } \\
\text { Frequency: } 18 \\
\text { Commonality: } 6 \text { ( } 4 \text { models in } 16 \\
\text { outcomes, } 1 \text { story, notes) }\end{array}$ \\
\hline Great Food & $\begin{array}{l}\text { - } \text { plant gardens. } \\
\text { - } \quad \text { (help people) grow (and share) food. } \\
\text { - } \text { increase consumption of healthy food. } \\
\text { - } \quad \text { provide education on healthy eating and growing food. } \\
\text { - } \quad \text { increase and share food and agricultural knowledge locally, } \\
\text { especially community knowledge. } \\
\text { - } \quad \text { build food production infrastructure. } \\
\text { - } \quad \text { use food as medicine and for healing. } \\
\text { - } \quad \text { create place through food. } \\
\text { - } \quad \text { increase (good) food access, security, justice, and sovereignty. }\end{array}$ & $\begin{array}{l}\text { In all } 5 \text { models as long-term } \\
\text { outcomes. } \\
\text { Frequency: } 127 \\
\text { Commonality: } 17 \text { (in documentary, } \\
10 \text { stories, } 5 \text { models in } 79 \\
\text { outcomes, notes) }\end{array}$ \\
\hline
\end{tabular}


Journal of Agriculture, Food Systems, and Community Development ISSN: 2152-0801 online

https:/ / www.foodsystemsjournal.org

Table 1 continued

\begin{tabular}{|c|c|c|}
\hline $\begin{array}{l}\text { Sustainable } \\
\text { Organization }\end{array}$ & $\begin{array}{l}\text { - build sustainable organizations that represent community } \\
\text { needs with adequate funding streams, community support, } \\
\text { strategic planning, infrastructure, capacity, successful } \\
\text { programs, brand recognition, and staff support to attract, } \\
\text { engage, and retain employees. }\end{array}$ & $\begin{array}{l}\text { In } 4 \text { models as long-term } \\
\text { outcomes. } \\
\text { Frequency: } 50 \\
\text { Commonality: } 5 \text { (in } 4 \text { models as } 43 \\
\text { outcomes and one activity, notes) }\end{array}$ \\
\hline Networks & $\begin{array}{l}\text { - build cross-sector relationships with peers, movement leaders, } \\
\text { agencies, decision-makers, universities and local food } \\
\text { businesses. }\end{array}$ & $\begin{array}{l}\text { In } 1 \text { model as long-term outcome. } \\
\text { Frequency: } 48 \\
\text { Commonality: } 6 \text { (in } 5 \text { models as } 35 \\
\text { outcomes and one activity, notes) }\end{array}$ \\
\hline $\begin{array}{l}\text { Motivational } \\
\text { Frame }\end{array}$ & $\begin{array}{l}\text { Meaning } \\
\text { - It is important to address the identified problems because... }\end{array}$ & Strength \\
\hline Recompense & $\begin{array}{l}\text { over generations some have been stripped of power, agency, } \\
\text { and choice in order to create greater power and profit for } \\
\text { others. It is therefore not charity for privileged people to serve } \\
\text { marginalized people in their work, but only the partial } \\
\text { repayment of an enormous debt. }\end{array}$ & $\begin{array}{l}\text { Frequency: } 18 \\
\text { Commonality: } 4 \text { (in notes, } 2 \text { stories, } \\
1 \text { partner website) }\end{array}$ \\
\hline
\end{tabular}

Five Diagnostic Frames

Based on our test criteria, combining frequency and commonality, five strong diagnostic frames emerged from our analysis: insufficient resources, broken food system, loss of place, degraded community, and constrained choice and responseability. We describe each below. See also Table 1 for a summary of these five diagnostic frames and the strength of their appearance in our data set.

\section{Insufficient resources}

CBO partners in Food Dignity noted working in communities where both organizations and individuals suffer as a result of limited access to resources. Time, money, knowledge, and infrastructure were identified as resources in these contexts. The resource of food was also mentioned; it was mentioned so frequently that we include those results in a separate category, below.

With descriptions of being "stretched thin" and of "exhausted resources," community partners articulated struggles regarding funding, time, and overextended staff (not a person of color, male, community; notes). On an individual level, one partner shared a personal story about her brother. Speaking to inadequate social support for people with disabilities, she explained, "He had tried to take care of himself. He had been growing veggies on his patio... But trying to live on disability after a work-related injury made it impossible for him to eat well no matter how many tomatoes he produced" (person of color, female, community; story
[Sequeira, 2015]).

Community partners felt strongly that academic institutions enjoyed access to unduly large means in comparison to what is made available to CBOs. Most of these assets ultimately stemmed from funding and included universities having abundant staffing, operational support, amassed savings, and employee benefit packages, at least in contrast with $\mathrm{CBO}$ resources. As an example, one partner noted, " ... for academics, consulting is part of what they're paid to do. Grassroots organizations don't have enough money to build that in" (not a person of color, female, community; notes). Community-based partners shared frustration at the specific discrepancy within Food D ignity wherein the USD A paid $22 \%$ unrestricted indirect costs to university partners in the project, but disallowed the $10 \%$ indirect costs proposed to be paid to the CBO s as part of their subawards for their Food Dignity work (see Porter \& Wechsler, 2018). This skewed resource distribution, leading to insufficient resources for CBOs in favor of academic institutions, also included decision-making power. As one community partner explained to the group, "I don't like the word 'allowed.' D on't restrict. Just let me do what it is I do- not, 'you're allowed to do that'" (not a person of color, female, community; notes).

Discussions of inadequate and denied resources often culminated in the lack of support available to community leaders. The following examples summarize this aspect of the Insufficient 
Resources diagnostic frame:

- "I'm in Food Dignity, but I'm not living in dignity. How is that? Have we talked about that? I'm doing work on this, but I can't afford to buy healthy, organic food" (person of color, female, community; notes).

- "The people most qualified to do the work may not be the best people at Excel and HR.... How do we bridge this gap for people? The leaders who are bridging those worlds are in the cross-hairs all the time" (not a person of color, female, academic; notes).

- "Think of all the capacity academics are given because we value their skills. What kind of package like that is there for grassroots organizers... and when the system breaks down, academics are forgiven in ways that we are never forgiven" (not a person of color, female, community; notes).

\section{Broken food system}

The broken food system frame encompasses the diagnoses of poor access to food and lack of control over production. Lack of access to food, and often specifically healthy food, is commonly identified as a cause of problems that CBOs and the Food Dignity collaboration are working to solve. Participants most often discussed access to food being limited by either geographic or monetary constraints. O ne community partner described his neighborhood environment saying, "We moved back to our housing projects and there was still no grocery stores, no fresh produce, no decent food for the community" (person of color, male, community; story [Rucker, 2015]). Another offered her experience with monetary barriers preventing access to adequate food: "kids in schools... that don't have enough access to food... they can't think, learn, until they get something to eat" (not a person of color, female, community; notes). The additional frame, encompassing an inability to grow one's own food thus leading to food access problems, is summarized by the explanation, "[We] were originally G reat Plains Indians, with huntergatherer lifestyles and diets based on natural foods. $\mathrm{G}$ rowing conditions are challenging. Accessible food now is dominated by external food suppliers and highly processed foods, fast food outlets, etc." (BMA, Sutter, Hargraves, \& D enning, 2017).

\section{Loss of place}

Relocation is at the root of many problems according to partners in Food D ignity. Community members have experienced loss of place historically, especially through European colonizers forcing Native Americans onto reservations and enslaving Africans and their descendants. Some communitybased partners have also experienced relocation in their own lifetimes by moving to new communities, emigrating from their native countries, and being incarcerated. One participant, who expressed a strong wish to regain a sense of belonging, explains, "I grew up in South Brooklyn, New Y ork, raised in the city projects. My mom was from Alabama and my father was an immigrant from Malaysia. People were always assuming I was Puerto Rican or D ominican, or something else" (person of color, female, community; story [Sequeira, 2015]).

Food D ignity participants also described losing a sense of place due to a change in social context, especially via a change in professional position. "As soon as my position shifted," recounted one community partner, "it felt very different, very weird. I didn't want to be seen as, 'oh she's the director now. She has power now'” (person of color, female, community; notes). O ne participant named this phenomenon a "third space," one occupied by community leaders who are intermediaries between marginalization and power, who walk-the-line between activist and sell-out (person of color, female, community; notes).

\section{Degraded community}

Community-based participants describe the degradation of their communities in a variety of ways. Poverty and limited economic opportunities were commonly cited as sources of problems. Some community-based Food Dignity partners also depicted their neighborhoods as abandoned and in states of disrepair. These factors lead to communities that are unsafe and that lack stimulating options for children and youth. Several of these phenomena are encompassed in the portrayal of one community partner's return home as an adult: 
"It was still a working-class community just with a lot less work. There's less stuff for kids to do there, fewer safe, healthy, and fun places for them to go. There are fewer small businesses in the area. There were more people living on the edge and more crime" (not a person of color, male, community; story [Neideffer, 2015]).

\section{Constrained choice and response-ability}

The final emergent diagnostic frame was how often individual choice and ability to respond and to thrive in the face of challenges are constrained by circumstances beyond an individual's control. For example, one partner noted, "it's not the money or the help that is the concern or the problem. [It's the] other things you have to deal with in life that hinder you when you want to go forward. Sometimes things go so deep down you just can't go forward" (person of color, male, community; notes). In this case, the speaker referred to a personal history of trauma and tragedy, one tightly linked with and caused by historical trauma and systemic oppression. Said another way, "people cannot handle that continuous stream of tragedies" (person of color, female, community; notes). Several partners specifically cited historical trauma and systems that limit agency, creating "odds that you and I could not have conceived" (person of color, woman, community; story [D aftary-Steel, 2015]). In the mini-documentary, two community partners mentioned explicitly how these systems constrain choice. O ne said, "not everyone feels empowered to make those choices, make the healthier choices... It's not that everyone just wanted a bodega on the corner. It's systematic how, how it ended up that way" (person of color, male, community; documentary). Another confirmed, "if you don't have the knowledge or you don't have the resources it doesn't matter how much choice you want to make. You can't make that choice" (person of color, female, community; documentary).

\section{Six Prognostic Frames}

Here we describe the six identified prognostic frames that met our strength criteria: reclaiming power, local economy, strong community, great food, sustainable organization, and networks. These frames regarding how to resolve food justice-related problems are described below. They are also listed in Table 1 with notes on the relative strength of each frame.

\section{Reclaiming power}

All five community partner organizations listed reclaiming power, or helping community members reclaim power, as long-term outcomes in their collaborative pathway models (Hargraves, D enning, BMA, DD F, ENYF, FLV \& WCP, 2017). The inclusion of reclaiming power in long-term outcomes indicates that these $\mathrm{CBO}$ s find the frame to be important, and its ubiquity further speaks to its strength. This reclaiming power frame appeared in three main forms: food sovereignty work, support for and development of community leaders, and connecting communities with and as decision makers. We illustrate the multifaceted aspect of reclaiming power by citing one relevant long-term outcome from each of the CBO's collaborative pathway models:

- "Reclaiming, restoring, and developing food sovereignty on our reservation" (BMA et al., 2017).

- "Enfranchising marginalized members of community" (D DF, Neideffer, Hargraves, \& D enning, 2017).

- "G reater fulfillment of personal and leadership potential for youth and adults" (ENYF, Vigil, Hargraves, \& D enning, 2017).

- "Increased involvement, voice, and power of previously marginalized, food insecure individuals and households" (FLV, Woodsum, Hargraves, \& D enning, 2017).

- "Increased representation and power of underrepresented groups in local food system decision-making" (WCP, Sequeira, Hargraves, \& D enning, 2017).

\section{Local economy}

Increasing local economic opportunities in and outside of the food system were offered as a means for addressing the identified problems in the longterm outcomes of four of five collaborative pathway models. Below is one example of a growing the local economy prognostic frame from each of 
these four in the form of desired long-term outcomes:

- "Increased economic vitality of Wind River Indian Reservation" (BMA et al., 2017)

- "Viable, sustainable network of foodproducing and supply-chain enterprises in Alameda County" (DDF et al., 2017).

- "G reater community-driven economic vitality" (ENYF et al., 2017).

- "Increased entrepreneurship and employment in food system for underrepresented community members" (WCP et al., 2017).

Perhaps offering a complimentary, yet also potentially contradictory frame, one CBO 's collaborative pathway model did not speak to an improved economy in the sense of more businesses, greater employment, or production and supply. Instead, its model envisions a "shift in community paradigm around sharing and giving the best" (FLV et al., 2017). While "sharing and giving" resources could be considered economic activity, this phrasing is itself a reframing of a capitalistic and monetized concept of economics in a North American context.

\section{Strong community}

When it comes to prescribing a strong community to address social problems, participants value community features such as support for residents, social opportunities, and safety. Feelings and perceptions are also valued, as the CBO partners in Food D ignity prioritize people feeling pride in their communities. Together, these components of the prognostic theme we call strengthening community are represented as long-term outcomes in four of the five collaborative pathway models:

- "Increased sense of community strength" (BMA et al., 2017).

- "Sustainable, vibrant, healthy community in Alameda County" (DDF et al., 2017).

- "East New York is a community people are proud of and enjoy living in" (ENYF et al., 2017).

- "Increased community connections, sense of belonging, worth, and possibility" (WCP et al., 2017).
As one community partner put it, "the more lines you weave through there, the stronger it is... Creating these tightly woven lines is creating community" (not a person of color, male, community; notes).

\section{Great food}

The great food frame is the most common of all the prognostic frames, appearing in the greatest diversity of data source types (see Table 1). This prognostic frame offers food production, sharing, and eating, as well as the sharing of food-related knowledge, as part of the solution to problems that Food Dignity partners and the project itself are trying to address. This frame derives its name from the conclusion of a digital story produced by the director of D DF, who is currently a captain in the Alameda County Sheriff's D epartment in California. Summarizing how DDF was improving lives in order to reduce crime by employing former inmates and local youth while increasing healthy food access in his community, the deputy explained, "Most importantly, we're making great food. To me that is great police work" (not a person of color, male, community; story [Neideffer, 2015]).

Food access, justice, and sovereignty appear as ends in and of themselves, including in the long term outcomes of all five collaborative pathway models. For many in the Food D ignity project, food also offers a means by which to accomplish other goals, including health and healing, personal change, and social change. For instance, one academic partner explained of the prisoner re-entry farm-training program mentioned above, "For most of them, learning to farm was a piece of trying to change their lives" (not a person of color, female, academic; story [Bradley, 2015]). As if in answer to the loss of place diagnostic frame, one community partner shared, "I needed roots so I planted a garden" (not a person of color, female, community; story [D unning, 2015]). Sharing knowledge about how to produce and prepare food was also part of this theme; for example, one urban farmer said, "Now I am able to share all I have learned about farming in the last four and half years with my old friends from my housing projects. People are able to help each other out and 
grow their own food" (person of color, male, community, story [Rucker, 2015]). A colleague noted, "I'm teaching my family about eating healthy and how to grow our own food" (male, community, story [Silva, 2015]).

\section{Sustainable organization}

In their collaborative pathway models, four of the five CBOs partnering in Food Dignity emphasized the importance of creating sustainable organizations. ${ }^{3}$ According to partners, many things are required for a sustainable organization, including adequate funding streams, community support, strategic planning, infrastructure, sufficient capacity, successful programs, brand recognition, and staff support to attract, engage, and retain employees. The Food Dignity focus on organizational sustainability includes continuing to learn and improve, such as the medium-term goal in one collaborative pathway model: to gain "increased knowledge of what works, what doesn't" (FLV et al., 2017). The $\mathrm{CBO}$ s also stressed the importance of growing responsibly in the sense of being true to community needs (e.g. "evolve[ing] in alignment with emerging community understanding" [FLV et al., 2017]) and the organizational mission (e.g. "sustainable changes that align with its mission" [ENYF et al., 2017]).

\section{Networks}

Networking emerged as an important part of solution framing in terms of its ability to expand capacity through collaboration and knowledge transfer and by offering a sense of solidarity. Referring to an international conference she had attended, one partner remarked, "there are other parts of the world coping, who understand what I'm going through... The problems are so big, but so is the movement. Y ou don't feel alone" (person of color, female, community; notes). Partners

\footnotetext{
${ }^{3}$ The one CBO that did not include this sustainable organization prognostic framing in its long-term outcomes was housed under a cooperative extension office, which ended its support for that CBO with the end of the Food Dignity partnership. In addition, another community partner has identified one of the Food Dignity project's greatest failures as not planning and providing adequately for supporting the $\mathrm{CBO}$ s in making their work sustainable.
}

stressed the value in communicating and working with other nonprofits and businesses, as well as universities, agencies, and decision-makers. Community partners also framed connecting with individual community members as a solution. Similarly, part of the networking frame relates to building community leaders through relationships, as in WCP's collaborative pathway model outcome, "national leaders in grassroots food justice work make connections with local individuals interested in food system work" (WCP et al., 2017).

\section{One Motivational Frame}

Through our work with Food Dignity, we identified one frame for motivating food justice action: recompense. This frame is singular and overarching. As illustrated above, partners employed the described diagnostic and prognostic frames both internally and publicly. By contrast, explicit use of this motivational frame for the food justice work was employed only internally, among Food Dignity partners. Initially only community partners used the recompense frame, often as an explanation to academic partners, and community partners continued to be its primary users throughout the project.

\section{Recompense}

The recompense frame that community partners used in Food Dignity suggests that those who have been systematically granted social privileges should recognize that it is their responsibility to use that privilege to bear the cost of "lifting up" those on whose backs the U.S. food system has been built. To become motivated by this recompense frame is not to accept individual blame nor assess guilt, but to recognize unearned, structural privilegesincluding those our society apportions by race, class and gender. This framing further asks for acknowledgment that privileges have been extracted through oppression and that equal treatment, by itself, cannot erase the inequities resulting from generations of some benefiting at the expense of others. According to the recompense framing of Food Dignity partners, redress and reparations are required if we are to create an equitable society.

In other words, Food D ignity partners' answer 
to the question, "why should I care about ending inequality in the food system?" is that our dominant food system in the U.S. was built on stolen land with stolen people and systematically supports the health of some and degrades that of others.

Food Dignity partners rarely used this recompense framing explicitly, but instead embedded it as implicit within diagnostic and prognostic frames. For example, one partner noted, "before slavery African people had a strong connection to the land. That connection was broken on the backs of slaves in the plantations. The spirit of love for the land was turned into shame and pain, and many of us now reject the land instead of honoring our connection to it" (person of color, male, community; story [Brangman, 2015]). Here, this partner's powerful melding of the relocation diagnostic frame and the great food prognostic frame combine as an implicit invitation to understand the premise of a recompense motivational frame.

Reclaiming indigenous and first-person expertise also fuels the recompense frame. For example, in an explicit use of this frame (less common than implicit uses), one partner shared her experience of her community's knowledge being stolen by academics. She explained, "I don't know how many times I've read articles of $\mathrm{PhD}$ folks, 'look what we found out!' Y eah, my mom told me that so many times... It hurts my soul and my heart that this is 'new knowledge' when it really isn't. This is a huge part of dignity, and Food D ignity. Reclaiming where this knowledge really comes from. Need to say it, be explicit about it. O wn it" (person of color, female, community; notes).

Though historical trauma and systemic oppression form the premise of the recompense frame, its motivating inverse is the enormous potential for progress if the call to redress these injustices is heeded. For example, as one community partner explained, "for people to grow their own food, you can't get any more dignity than that. We've been robbed of it by supermarkets, food stamps. The most healing thing I've ever seen" [referencing people growing their own food] (person of color, male, community; notes). Here, he implicitly introduced the recompense frame by offering the imperative that we should facilitate people growing their own food as one way to restore dignity to those from whom it has been robbed. As another partner observed, "None of the technical work will matter or succeed without the healing" (not a person of color, female, academic; notes).

\section{Discussion}

O ur results indicate that Food Dignity partners aim to address problems that are prominently, but not entirely, related to food. Only one of the five strong diagnostic frames that emerged was directly related to food (broken food system), suggesting that participants largely attribute food problems to underlying causes related to limited resources, loss of place and/ or loss of sense of belonging, degraded communities, and constrained choices. Similarly, prognostic frames suggest addressing the identified problems through several methods that do not necessarily involve food: reclaiming the power of marginalized people, (re)building local economies, creating strong communities and sustainable organizations, and building networks. The great food frame, however, also was strongly employed as a prognostic frame, including a broad range of specific solutions, from planting gardens to using food as a catalyst for achieving other goals.

We also found that Food Dignity partners employed diagnostic and prognostic frames much more commonly and explicitly than motivational frames. In addition, the one motivational frame identified- recompense- was employed explicitly only internally (not publicly) and mostly by community partners.

As in movements for environmental justice (see for example Bullard, Johnson, \& Torres, 2011) and analyses of structural violence (G altung, 1969), the uses outlined here of diagnostic, prognostic, and motivational frames by food justice actors in Food Dignity identify visible problems (such as food insecurity) as symptoms of deeper systemic and often historical societal issues of inequity. Like activists in related movements, Food D ignity partners understand and employ food-related strategies in this broader strucutral context.

As diagnostic framing applied to movements in general, Cress and Snow (2000) found that articulately assigning specific blame for a problem is a necessary condition for successful social movements. This finding, however, may apply best when 
blame is attributable to a much smaller segment of the population than in the case of food system injustice issues. We hypothesize that the recompense frame, which targets motivating people with systemic privilege (such as academic, male, and/ or white partners in Food Dignity), carries risks of backfiring if not employed strategically with audiences primed to hear it. As described by one food justice activist, "anyone can give charity and feel good about themselves, but giving justice to someone who demands it, that is harder to accept" (Longoria, Schlosser, Keshari, Fish, \& Rawal, 2014). Our personal experience in the project suggests that many of the community partners in Food Dignity generously and strategically worked over the seven years of the partnership to help many of the academic, male, and white partners understand, and become motivated by, this frame. We do know that it came to motivate each of us based on the individual ways in which we carry privilege and oppression.

McCammon et al.'s (2007) study offers additional potential guidelines for effective framing. Explicitly rebutting opposing frames- those that conflict with goals of the food justice movementmay improve the efficacy of strategic framing. An example of an opposing frame as identified by a community partner is, "the City would have you think, 'We're okay, Walmart's donating food" (not a person of color, female, community; notes), suggesting that food-insecure people simply need more donated food, not changes to the food system. According to McCammon et al. (2007), employing direct diagnostic or prognostic rebuttals about why donations from Walmart are insufficient may help foster food movement goals.

Another promising strategic framing strategy offered in the literature is that adapting food justice frames to make connections with disruptive events in society will increase a movement's chances for success (McCammon et al., 2007). For example, rising discontent with relationships between police departments and African American communities, general calls to resist threats to U.S. democracy, and concerns about the future of public lands are all issues that might offer opportunities onto which one can "hook" some forms of food justice strategic framing.
Sbicca (2012) posits that effective frames should "resonate among [food justice] activists" (p. 463) to be consistent with the values of the movement. O ur identified speaker demographics suggest that community, rather than academic, partners dominantly use the strongest frames in Food Dignity and that partners across races and two genders use these frames (see Strength column of Table 1). In other words, the strong frames used by Food Dignity partners not only resonate with, but were generated by, food justice activists, many of whom have personal experience with food injustice. Now the Food Dignity collaboration must amplify these strategic food justice frames. These are the voices that must be heeded if the food justice movement is to succeed where others have failed in reaching their goals (Slocum, 2011). This investigation of social movement framing in the Food D ignity partnership may help address the call for a way of identifying and developing diagnostic, prognostic, and motivational frames "premised on an open understanding of [food justice] that are then integrated into movement-building efforts" (Sbicca, 2012, p. 464).

Further studies should focus on understanding the impact of these framings on food justice outcomes, including by using empirical methods such as those established in McCammon et al. (2007) and by identifying arenas of overlap with other movements that may be ripe for collaboration. Also, per the relative timidity of food movement framings mentioned in the literature review, trialing the effectiveness of more radical and oppositional framing may be worth conducting.

Since people learn best from contextualized examples (Flyvbjerg, 2006), it is our hope that this study can offer valuable information to activists wishing to strengthen the clarity and potency of social movement framing in food justice and beyond.

\section{Conclusion}

Effective framing is an influential part of building a successful social movement (Cress \& Snow, 2000; McCammon et al., 2007; McVeigh et al., 2004), and explicitly identifying food justice movement framing is a key step toward both honing and evaluating these framing strategies. Using the case of 
the Food Dignity project and partnership, our results here are among the first to identify diagnostic, prognostic, and motivational frames used in the food justice movement.

Food Dignity community partners consistently diagnosed causes of food injustice as inequitable and insufficient resource distribution, a food system that fails to provide sufficient access to healthy food, dislocation, degraded communities, and systemic constraints on choice and individual capacity to respond. Solution frames included reclaiming power, growing local economies, strengthening communities, growing and sharing great food, sustaining $\mathrm{CBO}$ s, and networking in the movement. Partners employed one thematic motivational frame of recompense, mostly implicitly and mostly in house among project partners. We also observe that Food D ignity community partners were active in creating and utilizing the frames noted.

Past empirical work on effective social move- ment framing suggests that Food Dignity partners may have room to use more direct motivational frames publicly, to rebut opposing frames more explicitly, and possibly to point more specifically to those who are complicit in the problems they identify. However, whether these lessons from other contexts apply within the food justice movement is a decision best left to front-line activists.

In keeping with Sbicca's (2012) case study with People's Grocery, most of the food justice frames used by Food Dignity project partners point to the root of the problem as systemic social oppression. Solution frames do include producing and sharing great food, but that is only one small part of the solution. As an academic-based partner noted in her digital story, the community-based partner who inspired the name of the entire Food Dignity project said that "the work is ultimately about dignity" (Sequeira in Porter, 2015).

\section{References}

Aarons, G . (2012, A pril). Public comment on Food D ignity as a co-panelist on Expanding the frontiers of nutrition research: New questions, new methods and new approaches. Symposium session convened by D. L. Pelletier \& C. M., Porter at American Society for Nutrition/ Experimental Biology, San Diego, CA.

ATLAS.ti G mbH. (2008). ATLAS.ti: qualitative data analysis (Version 5.6.3). Berlin. http:// www.atlasti.com/

Bateson, G . (1972). Steps to an ecology of mind: Collected essays in anthropology, psychiatry, evolution, and epistemology. Chicago: University of Chicago Press.

Blue Mountain Associates, Inc. [BMA]. (n.d.). Blue Mountain Associates, Inc. Retrieved from http:/ / www.bluemountainassociates.com/

BMA, Sutter, V., Hargraves, M., \& D enning, C. (2017). Blue Mountain Associates: Food Dignity project, a collaborative patbway model. Retrieved from https:/ / www.fooddignity.org/ collaborative-pathway-models

Bradley, K. (Producer). (2015). Field notes [Paths to Food Dignity video]. Retrieved from https:/ / www.youtube.com/ watch?v=VTzOJFGN3j4

Bradley, K., \& Herrera, H. (2016). D ecolonizing food justice: Naming, resisting, and researching colonizing forces in the movement. Antipode, 48(1), 97-114. https:/ / doi.org/ 10.1111/ anti.12165

Brangman, D . (Producer). (2015). Roots rising [Paths to Food D ignity video]. Retrieved from https:// www.youtube.com/ watch?v=JW40 uOLVebU

Buechler, S. M. (2000). Social movements in advanced capitalism. New Y ork: Oxford University Press.

Bullard, R. D ., Johnson, G. S., \& Torres, A. O. (2011). Environmental health and racial equity in the United States: building environmentally just, sustainable, and livable communities. Washington, D.C.: American Public Health Association.

Cabbil, L. (2012, May). Comment as anti-racism workshop faciliator at the 3rd Food Dignity national team meeting, Detroit, MI.

Chappell, J. (2013, O ctober). Public comment made while serving on a panel of keynote speakers at Yale Food Systems Symposium, Yale University, New Haven, CT.

Community-Campus Partnerships for Health. (2014). Food Dignity receives 13th annual CCPH Award. Retrieved from https:/ / ccph.memberclicks.net/ assets/ D ocuments/Award/ pressrelease-award14.pdf

Cress, D . M., \& Snow, D . A. (2000). The outcomes of homeless mobilization: The influence of organization, disruption, 
Journal of Agriculture, Food Systems, and Community D evelopment

ISSN: 2152-0801 online

https:/ / www.foodsystemsjournal.org

political mediation, and framing. American Journal of Sociology, 105(4) 1063-1104. https:/ / doi.org/ 10.1086/ 210399

D aftary-Steel, S. (Producer). (2015). Seeing differently [Paths to Food Dignity video]. Retrieved from https:// www.youtube.com/ watch?v=f7jITKvHb0w

Dig D eep Farms [D D F]. (n.d.). About us. Retrieved from http:/ / digdeepfarms.com/ about-us/

DD F, Neideffer, M., Hargraves, M., \& D enning, C. (2017). Dig Deep Farms in its larger context, a collaborative pathway model. Retrieved from https:/ / www.fooddignity.org/ collaborative-pathway-models

Dunning, L. (Producer). (2015). The grace to receive [Paths to Food Dignity video]. Retrieved from https:/ / www.youtube.com/ watch?v=ecMqU1JagW4

East New York Farms! [ENY F]. (2010). East New York Farms! Retrieved from http:/ / www.eastnewyorkfarms.org/

ENYF, Vigil, D ., Hargraves, M., \& D enning, C. (2017). East New York Farms! A collaborative pathway model. Retrieved from https:/ / www.fooddignity.org/ collaborative-pathway-models

Fairbairn, M. (2012). Framing transformation: The counter-hegemonic potential of food sovereignty in the US context. Agriculture and Human Values, 29(2), 217-230. https:/ / doi.org/ 10.1007/ s10460-011-9334-x

Feeding Laramie Valley [FLV]. (n.d.). About us. Retrieved from http:/ / www.feedinglaramievalley.org/ \#!about-us/ cjg9

FLV, Woodsum, G. M., Hargraves, M., \& Denning, C. (2017). Feeding Laramie Valley: A collaborative patbway model. Retrieved from https:// www.fooddignity.org/ collaborative-pathway-models

Flyvbjerg, B. (2006). Five misunderstandings about case-study research. Qualitative Inquiry, 12(2), 219-245. https:/ / doi.org/ 10.1177/ 1077800405284363

Food Dignity. (n.d.). Welcome. Retrieved from http:// fooddignity.org/

Food Dignity. (2015). Place, environment, and science: Paths to Food Dignity: Digital stories of personal journeys to food justice work. Retrieved from https:/ / www.youtube.com/ playlist?list=PL2zMrq22-Y2tanD zKhB6L945wpkkgQEEe

Galtung, J. (1969). Violence, peace, and peace research. Journal of Peace Research, 6(3), 167-191. https:// doi.org/ 10.1177/ 002234336900600301

Goffman, E. (1974/ 1986). Frame analysis: An essay on the organization of experience. York, PA: Maple Press.

Hargraves, M., \& D enning, C. (2018). V isualizing expertise: Collaborative Pathway Modeling as a methodology for conveying community-driven strategies for change. Journal of Agriculture, Food Systems, and Community Development, 8(Suppl. 1), 101-115. https:/ / doi.org/ 10.5304/ jafscd.2018.08A.005

Hargraves, M., D enning, C., BMA, D D F, ENYF, FLV \& Whole Community Project [WCP]. (2017). Food Dignity Collaborative Pathway Models. Retrieved from https:/ / www.fooddignity.org/ collaborative-pathway-models

Longoria, E., Schlosser, E., Keshari, S., Fish, H. (Producers) \& Rawal, S. (D irector). (2014). Food chains [Motion picture]. United States: Screen Media Films \& Sunfilm Entertainment.

Luotto, M. (Producer). (2015). Tracing the patbs: Telling stories of Food Dignity [D ocumentary short]. Retrieved from https:// www.youtube.com/ watch?v=-KncokFttEM

Martin, G. (2015). Understanding social movements. London: Routledge.

McCammon, H. J., Muse, C. S., Newman, H. D., \& Terrell, T. M. (2007). Movement framing and discursive opportunity structures: The political successes of the US women's jury movements. American Sociological Review, 72(5), 725-749. https:// doi.org/ 10.1177/ 000312240707200504

McV eigh, R., Myers, D . J., \& Sikkink, D . (2004). Corn, Klansmen, and Coolidge: Structure and framing in social movements. Social Forces, 83(2), 653-690. https:/ doi.org/ 10.1353/ sof.2005.0019

Merriam, S. B. (2009). Qualitative research: A guide to design and implementation: Revised and expanded from qualitative research and case study applications in education. San Franscisco: Jossey-Bass.

Miles, M. B., \& Huberman, A. M. (1994). Qualitative data analysis: An expanded sourcebook. Thousand Oaks, CA: Sage.

Minkler, M. (1999). Personal responsibility for health? A review of the arguments and the evidence at century's end. Health Education \& Behavior, 26(1), 121-141. https:/ / doi.org/ 10.1177/ 109019819902600110

Mooney, P. H., \& Hunt, S. A. (2009). Food security: The elaboration of contested claims to a consensus frame. Rural Sociology, 74(4), 469-497. https:/ / doi.org/ 10.1111/j.1549-0831.2009.tb00701.x 
Neideffer, M. (Producer). (2015). When good food makes for good policing [Paths to Food D ignity video]. Retrieved from https:// www.youtube.com/ watch?v=zuMNSAH6zlE

Porter, C. M. (Producer). (2015). The truth about magic [Paths to Food Dignity video]. Retrieved from https:// www.youtube.com/ watch?v=5Jb5udXp8fM

Porter, C. M. (2018). Triple-rigorous storytelling: A PI's reflections on devising case study methods with five community-based food justice organizations. Journal of Agriculture, Food Systems, and Community Development, 8(Suppl. 1), 37-61. https:// doi.org/ 10.5304/ jafscd.2018.08A.008

Porter, C. M., Herrera, H., Marshall, D ., \& Woodsum, G. M. (2014). Shared voices, different worlds: Process and product in the Food Dignity action research project. Gateways: International Journal of Community Research and Engagement, 7(1), 116-128. https:/ / doi.org/ 10.5130/ ijcre.v7i1.3399

Rucker, P. (Producer). (2015). Fresh start [Paths to Food Dignity video]. Retrieved from https:// www.youtube.com/ watch?v=fjnIjAvLUJo

Sbicca, J. (2012). G rowing food justice by planting an anti-oppression foundation: O pportunities and obstacles for a budding social movement. Agriculture and Human Values, 29(4), 455-466. https:/ / doi.org/ 10.1007/ s10460-012$\underline{9363-0}$

Sequeira, E. J. (Producer). (2015). Sankofa [Paths to Food Dignity video]. Retrieved from https:// www.youtube.com/ watch?v=wvXiHs336uE

Silva, M. (Producer). (2015). My new life [Paths to Food Dignity video]. Retrieved from https:/ / www.youtube.com/ watch?v=yI3wjw1Nn84

Slocum, R. (2011). Race in the study of food. Progress in Human Geography, 35(3), 303-327. https:/ / doi.org/ 10.1177/ 0309132510378335

Snow, D . A., \& Benford, R. D . (1988). Ideology, frame resonance, and participant mobilization. International Social Movement Research, 1(1), 197-217.

Starr, A. (2010). Local food: A social movement? Cultural Studies $\leftrightarrow$ Critical Methodologies, 10(6), 479-490. https:/ / doi.org/ 10.1177/ 1532708610372769

Whole Community Project [WCP] at Food Dignity. (n.d.). Whole Community Project. Retrieved from http:/ / www.fooddignity.org/ whole-community-project

WCP, Sequeira, E. J., Hargraves, M., \& D enning, C. (Producer). (2017). Whole Community Project: A collaborative patbway model. Retrieved from https:/ / www.fooddignity.org/ collaborative-pathway-models 